\title{
Zinza, a New Genus of Rhinotorine Flies from Northern Queensland, Australia (Diptera: Heleomyzidae)
}

\author{
Bradley J. Sinclair ${ }^{1}$ \& DAVID K. MCAlpine \\ Australian Museum, 6 College Street, Sydney NSW 2000, Australia. \\ ${ }^{1}$ Present address: Department of Environmental Biology, \\ University of Guelph, Guelph, Ontario, N1G 2W1 Canada.
}

\begin{abstract}
Zinza grandis n.gen., n.sp. (Diptera: Heleomyzidae) is described from the Atherton Tableland in northern Queensland. Zinza is classified in the tribe Rhinotorini and is related to Cairnsimyia Malloch and Zentula D. McAlpine. A comparison of these three genera is provided. The egg of $Z$. grandis is also described.
\end{abstract}

Sinclair, Bradley J. \& David K. McAlpine, 1995. Zinza, a new genus of rhinotorine flies from northern Queensland, Australia (Diptera: Heleomyzidae). Records of the Australian Museum 47(3): 225-230.

The Heleomyzidae (Diptera) are commonly found in temperate forests in most regions, but in the tropics the family inhabits mainly cooler mountainous areas. The tribe Rhinotorini is exceptional in that it is represented in tropical lowlands, both in the Americas and in Australasia, though it extends into temperate areas (e.g., southern Chile, Tasmania). Adult rhinotorines have been found at exudations on tree trunks in Australia, Papua New Guinea, and South America. The only recorded rhinotorine larva lives in cerambycid tunnels in trees (D. McAlpine, 1968). In this paper, the first new Australian rhinotorine genus discovered since the generic revision of D. McAlpine (1985) is described.

Terms used for adult structures primarily follow those of J. McAlpine (1981), except male terminalia where the terms of Cumming et al. (1995) are used. To facilitate observation, the terminalia were macerated in hot $85 \%$ lactic acid and immersed in glycerin. Specimens cited in this paper are housed in the Australian Museum,
Sydney (AMS) and CSIRO, Division of Entomology, Canberra (ANIC).

\section{Zinza n.gen.}

Type species. Zinza grandis n.sp.

Description. Large flies, with most of the general characters of the Rhinotorini (D. McAlpine, 1985).

Head (Fig. 1) moderately excavated on vertex, ocelli thus not visible in profile; posterior ocelli much closer to each other than to anterior ocellus; ocellar bristles closely approximated, inserted posteriorly to anterior ocellus; vibrissa and 2-3 closely placed peristomial bristles distinct but small; central cheek bristle absent; hypofacial short and narrow. Arista long-plumose beyond basal fifth. Palpus short and compressed. 


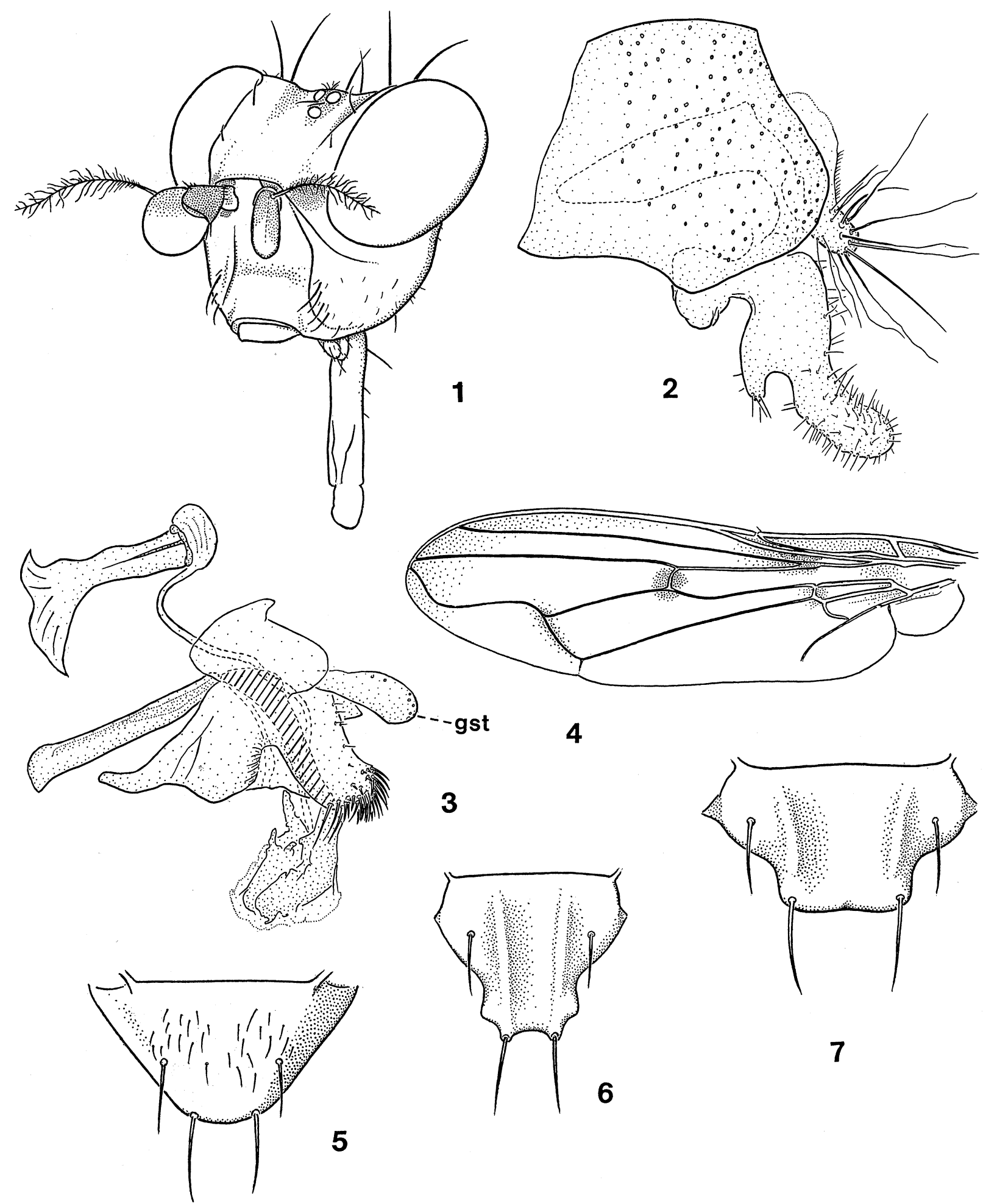

Figs 1-7. 1, Zinza grandis head. 2, Z. grandis epandrium, surstylus, cercus. 3, Z. grandis hypandrium, phallus, ejaculatory apodeme. 4, Z. grandis wing. 5, Cairnsimyia sydneiensis D. McAlpine scutellum. 6, Neorhinotora aristalis (Fischer) scutellum. 7, Z. grandis scutellum. Abbreviation: gst, gonostylus. 

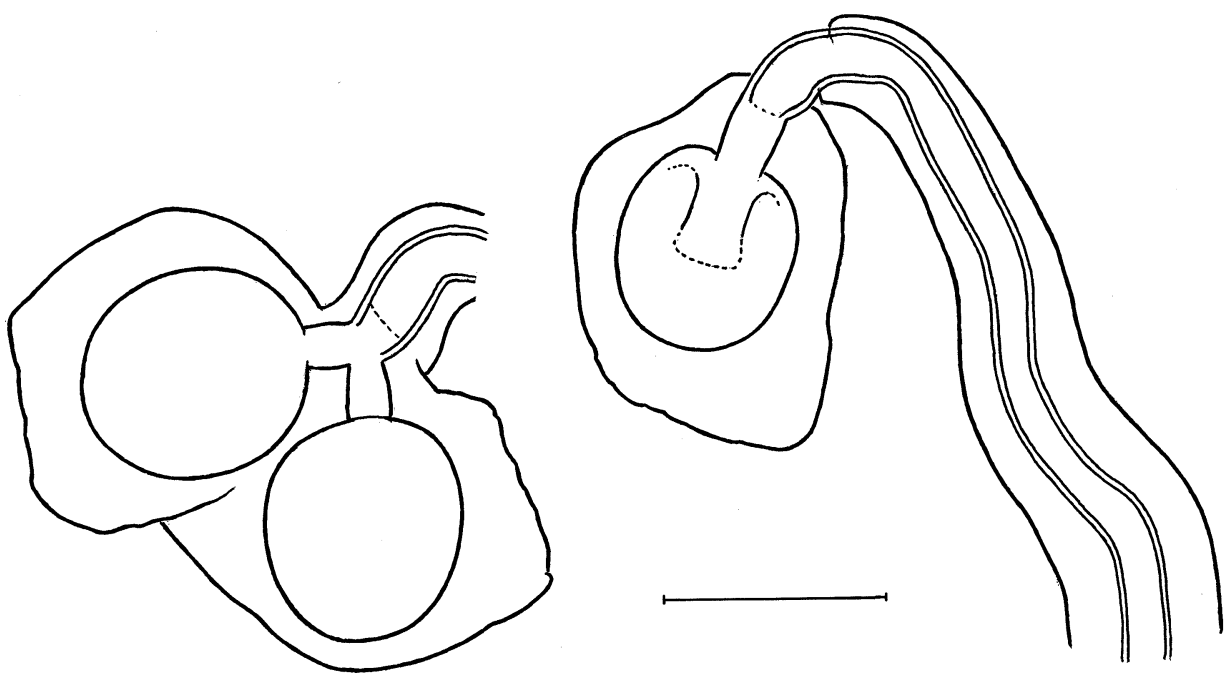

Fig. 8. Spermathecae of Zinza grandis. Scale $=0.1 \mathrm{~mm}$.

Thorax: scutellum with shallow median channel, without setulae (Fig. 7); proepisternum with fine setulae above, without even vestige of proepisternal bristle below; anepisternum with long scattered setulae, anepisternal bristle lacking; metasternum strongly setulose. Fore coxa enlarged and inflated; fore femur stout, apparently raptorial, less so in female; fore and mid tibiae with distinct, short, preapical dorsal bristle. Wing with few markings, mainly on crossveins (Fig. 4); costa with 1 or 2 anterior spines before subcostal break and often 1 or 2 beyond; postcostal and alular margins with modified fringe; distal separation of Sc and $R_{1}$ greater than length of humeral crossvein; distal section of $M_{1}$ sigmoid, strongly convergent with $\mathrm{R}_{4+5}$ apically; dm-cu oblique.

Male postabdomen: resembling that of Cairnsimyia Malloch (details in description of $Z$. grandis).

Female postabdomen: tergites and sternites largely unmodified; 3 spermathecae present.

Remarks. Adults of the type species of this genus run to couplets 13 and 14 in the key to Australian heleomyzid genera of D. McAlpine (1985), where the choices are Heleomicra D. McAlpine, Zentula D. McAlpine and Cairnsimyia. The plumose arista, setulose metasternum, and strongly apically convergent veins $R_{4+5}$ and $M_{1}$ separate Zinza from these genera and all other taxa of Rhinotorini known to us. For a comparison with Cairnsimyia and Zentula, see Table 1.

Etymology. The generic name is a contraction of the Latin zinzala, a kind of gnat. Its gender is feminine.
Zinza grandis n.sp.

Figs $1-4,7,8$

Material examined. HoLOTYPE male. North Queensland: $4 \mathrm{~km}$ up Mount Edith Road, near Tinaroo Dam, $800 \mathrm{~m}, 17^{\circ} 05^{\prime} \mathrm{S} 145^{\circ} 38^{\prime} \mathrm{E}$, fruit trap, 22-27 Apr. 1994, M.S. Moulds \& B.J. Sinclair (AMS). PARATYPES: North Queensland: 1 male, same data as holotype (ANIC); 1 female, Longlands Gap, Atherton district, $1150 \mathrm{~m}, 17^{\circ} 28^{\prime} \mathrm{S} 145^{\circ} 29^{\prime} \mathrm{E}$, Malaise trap, Feb.-Mar. 1995, P. Zborowski (AMS).

Description. Coloration: head pale yellow; frons shiny gold, with 2 black spots at base of antennae; ocellar triangle dark; vertex with black spot on either side of postverticals; dark spot at base of vibrissa, larger and more distinct in female; scape, pedicel and basal half of first flagellomere brown; ventral surface of first flagellomere mostly pale yellow, less extensively so in female; palpus pale yellow with dark apical setae; proboscis brown. Thorax fulvous; mesoscutum with symmetrical patches of pale yellow, including postpronotal lobe; scutellum brown with median apical yellow marking; pleura with weak brown horizontal stripe on upper margin of proepisternum and anepisternum, brown mark above fore coxa, weak brown stripe across lower margin of anepisternum, upper half of katepisternum, anepimeron, meron, and katatergite. Fore and mid coxae yellow, hind coxa and trochanter brown; fore and mid femora yellow, hind femur brown; apices of femora with black band; tibiae with subbasal and apical black bands; tarsomeres 1-4 yellow, tarsomere 5 dull brown. Wing: membrane yellowish, more intensely so towards base; brown spot 
Table 1. Comparison of the genera Zinza, Cairnsimyia and Zentula.

\begin{tabular}{|c|c|c|}
\hline Zinza & Cairnsimyia & Zentula \\
\hline - arista plumose & - arista with micro-pubescence & - arista with micro-pubescence \\
\hline $\begin{array}{l}\text { - posterior ocelli much closer to } \\
\text { each other than to anterior ocellus }\end{array}$ & $\begin{array}{l}\text { - posterior ocelli not much approx- } \\
\text { imated }\end{array}$ & $\begin{array}{l}\text { - posterior ocelli not much approx- } \\
\text { imated }\end{array}$ \\
\hline $\begin{array}{l}\text { - ocellar bristles closely approx- } \\
\text { imated }\end{array}$ & - ocellar bristles widely separated & - ocellar bristles widely separated \\
\hline - vertex depressed & - vertex depressed & - vertex not depressed \\
\hline $\begin{array}{l}\text { - lower part of face prominent along } \\
\text { most of margin }\end{array}$ & $\begin{array}{l}\text { - lower part of face narrowly } \\
\text { prominent, the prominence im- } \\
\text { pressed at sides }\end{array}$ & $\begin{array}{l}\text { - lower part of face prominent along } \\
\text { most of margin }\end{array}$ \\
\hline - palpus short, compressed & - palpus short, compressed & - palpus elongate, cylindrical \\
\hline $\begin{array}{l}\text { - vibrissa and associated peristomial } \\
\text { bristles present }\end{array}$ & $\begin{array}{l}\text { - vibrissa and usually peristomial } \\
\text { bristles present }\end{array}$ & $\begin{array}{l}\text { - vibrissa and peristomial bristles } \\
\text { absent }\end{array}$ \\
\hline - prosternum without setulae & - prosternum with setulae & - prosternum with setulae \\
\hline - anepisternum sparsely setose & - anepisternum with setulae & - anepisternum without setulae \\
\hline - proepisternal bristle absent & $\begin{array}{l}\text { - proepisternal bristle present, often } \\
\text { small }\end{array}$ & - proepisternal bristle present \\
\hline $\begin{array}{l}\text { - prescutellar acrostichal bristles } \\
\text { absent }\end{array}$ & $\begin{array}{l}\text { - prescutellar acrostichal bristles } \\
\text { variable }\end{array}$ & $\begin{array}{l}\text { - prescutellar acrostichal bristles } \\
\text { present }\end{array}$ \\
\hline - scutellar setulae absent & - scutellar setulae present & - scutellar setulae present \\
\hline - scutellum dorsally channelled & - scutellum dorsally flattened & - scutellum dorsally flattened \\
\hline - metasternum strongly setulose & - metasternum bare & - metasternum bare \\
\hline $\begin{array}{l}\text { - seriate spots lacking in cells } r_{1} \text { and } \\
\mathbf{r}_{2+3}\end{array}$ & $\begin{array}{l}\text { - seriate spots present in cells } r_{1} \text { and } \\
\mathrm{r}_{2+3}\end{array}$ & $\begin{array}{l}\text { - seriate spots present in cells } r_{1} \text { and } \\
\mathrm{r}_{2+3}\end{array}$ \\
\hline $\begin{array}{l}\text { - vein } \mathrm{M}_{1} \text { strongly curved anteriorly } \\
\text { at apex }\end{array}$ & - $\mathrm{M}_{1}$ not strongly curved anteriorly & - $\mathrm{M}_{1}$ not strongly curved anteriorly \\
\hline $\begin{array}{l}\text { - apical and posterior fringe of wing } \\
\text { with modified armature }\end{array}$ & $\begin{array}{l}\text { - apical and posterior fringe of wing } \\
\text { normal }\end{array}$ & $\begin{array}{l}\text { - apical and posterior fringe of wing } \\
\text { normal }\end{array}$ \\
\hline
\end{tabular}

on crossvein $\mathrm{r}-\mathrm{m}$ and $\mathrm{Rs}$ fork, crossing cell $\mathrm{r}_{1}$; small brown spot at apex of cell bm; smoky suffusion present around crossvein dm-cu and wing apex. Haltere pale yellowish. Abdomen bright golden yellow; lateral margins of tergites 1-2 with brown suffusion.

Head (Fig. 1): ocellar and postocellar regions forming slight longitudinal convexity within broader frontal excavation; face concave in profile, with lower margin very prominent; postvertical bristle much longer than ocellar; fronto-orbital bristles 2, posterior one short but distinct, anterior one smaller, sometimes little differentiated from frontal setulae. First flagellomere subcircular, compressed. Clypeus shallow, but anteriorly prominent; proboscis elongate, with small apparently membranous labella.

Thorax somewhat elongate; scutellum without setulae, shape somewhat resembling that of Neorhinotora aristalis (Fischer) (Figs 6,7), with slight longitudinal ridge on each side of dorsal channel, concavity on each side between anterior and posterior bristles, and slightly bigibbous apex; prosternum narrow, weakly sclerotised. Chaetotaxy: 1 humeral, 2 notopleurals, 1 
supra-alar, 1 postalar, 1 posterior inter-alar, 1 posterior dorsocentral, 2 scutellars; acrostichal, proepisternal, and anepisternal bristles absent; katepisternum with 2 widely spaced bristles and long setulae. Males with mollisetae (see D. McAlpine [1991: 31] for definition) on ventral surface of katepisternum, metasternum, mid and hind coxae, and ventral surface of fore femur; hind trochanter simple (lacking brushed tubercle, present in males of Zentula species). Fore femur with several dorsal bristles; mid femur with several anterior bristles near and beyond middle; male mid femur with small socket-based ovoid anteroventral peg just beyond basal third; hind femur with few dorsal bristles and rather dense ventral setulae; male hind femur stout, apparently raptorial; female hind femur broad, longer than mid femur; fore and hind tibiae shorter than femora, slightly curved with subangular basal thickening; mid tibiae with several short, thick ventroapical spur-like bristles, among which one (female) or 2 (male) form longer spurs; all tibiae with large ventroapical bight (only slightly developed in other rhinotorines, presumably enabling tarsus to be sharply flexed ventrally against tibia); fore basitarsus slightly depressed; mid basitarsus subcylindrical; hind basitarsus obliquely compressed; tarsomeres 1-4 of mid leg with ventrolateral comb of stout black bristles. Wing: cell $r_{1}$ without supernumerary crossveins.

Abdomen: tergites 2-5 with long, silky golden lateral setae; sternite 1 well sclerotised, quadrate, setulose laterally.

Male postabdomen (Figs 2,3): protandrial sclerites resembling those of Cairnsimyia uniseta D. McAlpine (see D. McAlpine, 1985, fig. 92); tergite 6 reduced, bare, separate from other sclerites; one large spiracle on either side of tergite 6 , remaining spiracles absent; small sclerite present on right side of sternite 8; epandrium with long mollisetae; surstylus trilobed, apical lobe with short bristles; ventroapical lobes of hypandrium with dense patch of dark bristles; gonostylus laterally compressed, apically expanded; ejaculatory apodeme slender with T-shaped base; basiphallus forming slender sclerotised rod; distiphallus with complex sclerotisation, anteriorly reflexed; cerci short, rounded, fused anteroventrally, with long dark undulating bristles.

Female postabdomen: sternite 6 divided by median desclerotisation; cerci short, slender, well separated and free distally. Two spermathecae on common duct plus slightly smaller spermatheca on separate duct, each with irregular outer envelope and subspherical, almost smooth black cuticular lining (Fig. 8); black pigment decurrent for short distance on lining of duct; duct deeply inserted into vesicle (at least in single spermatheca, paired ones too intensely pigmented to enable interpretation of internal structure), with cellular (?muscular) envelope in part much thickened proximally to vesicle. Egg whitish, elongate-ovoid, roughly bilaterally and biterminally symmetrical, except for slight impression at one end from which a small cup-shaped structure protrudes; surface with numerous prominent longitudinal ridges, over 20 at mid-length, some of them not reaching ends, otherwise apparently without external processes; length $1.2 \mathrm{~mm}$, width 0.44 $\mathrm{mm}$.

Dimensions: total length, male (abdomen deflexed) 7.7-7.8 $\mathrm{mm}$, female $9.7 \mathrm{~mm}$; length of thorax, male $4.4 \mathrm{~mm}$, female $4.7 \mathrm{~mm}$; length of wing, male 9.7$9.8 \mathrm{~mm}$, female $10.0 \mathrm{~mm}$.

Etymology. The specific epithet "grandis" refers to its much larger size compared to species of Cairnsimyia and Zentula.

\section{Distribution}

This species is known only from the Atherton Tableland, which rises more than $600 \mathrm{~m}$ above the coastal plain south-west of Cairns in northern Queensland. The Atherton Tableland is one of a series of temperate areas that represent a mesothermal "archipelago". Mesothermal refers to a plant group with optimum temperatures for growth of $19-22^{\circ} \mathrm{C}$ (Nix, 1991). In northern Queensland, tropical and subtropical lowlands separate the tablelands (or mesothermal "islands") from similar mesothermal areas of montane New Guinea and southern Australia. These mesothermal environments of northern Queensland represent regions of high endemism in both vertebrates (Nix, 1991) and invertebrates.

Of the five other heleomyzid species known from the Atherton Tableland (including the less elevated Kuranda district) only one, Diplogeomyza immaculata D. McAlpine, appears to be endemic (D. McAlpine, 1967). Three others, Diplogeomyza tridens D. McAlpine, D. signata D. McAlpine, and Cairnsimyia cavifrons Malloch, extend from the Atherton Tableland southwards into New South Wales. Pentachaeta sp. (undescribed "sp. E" in AMS) extends from Kuranda, at the northern edge of the Tableland, south to the Clarke Range-Eungella district (c. $21^{\circ} 10^{\prime} \mathrm{S}$ ), and is thus probably restricted to mesothermal areas of the tropics. Other Pentachaeta species are restricted to temperate Australia.

\section{Biology}

Specimens from Mount Edith Road were collected in a banana baited fly trap, suspended approximately 1.5-2 $\mathrm{m}$ above the ground in upland rainforest. The fly trap is similar to a lobster trap, consisting of a nylon mesh cylinder, with bait suspended near the bottom. The insects are caught alive and removed from the trap using an aspirator. 


\section{Comparative notes}

Zinza conforms to the description of the tribe Rhinotorini (D. McAlpine, 1985) except that the arista is longplumose and inserted slightly closer to the base than to the apex of first flagellomere. Within this tribe, Zinza belongs in subtribe 1 as characterised by D. McAlpine (1985: 232-233), although the description must be extended to include forms without scutellar setulae (Figs 5-7). This subtribe includes the two other Australian genera Cairnsimyia and Zentula, whereas subtribes 2 and 3 include only New World taxa.

The distinctive subtruncate, dorsally channelled scutellum resembles that of the Neotropical rhinotorine genus, Neorhinotora Lopes (Fig. 6). In addition, $\mathrm{M}_{1}$ is also strongly curved forward distally to meet $R_{4+5}$ in the Chilean genus Mayomyia Malloch (Malloch, 1934, fig. 11). However, Zinza is only distantly related to these two genera, the latter genus belonging in a distinct tribe (Mayomyiini).

The small ventral peg on the mid femur of Zinza has not been observed in other rhinotorine taxa, and is malerestricted. As in many other schizophoran flies, mollisetae in this genus are much less developed in females.

Hennig (1958) recorded two spermathecae for Rhinotora pluricellulata Schiner (sic), and J. McAlpine (1987) described and figured two spermathecae for Neorhinotora diversa (Giglio-Tos). As two and three are both frequent spermathecal counts in Heleomyzidae (four in some Suillia species), and as both numbers are present in the tribes Heleomyzini and Allophylopsini (Hennig, 1958; Schneider, 1982; pers. obs. D. McAlpine), it is not surprising that this variation should be present in Rhinotorini. The egg of Zinza grandis differs greatly from those of Rhinotora and Neorhinotora as figured by Lopes (1935, figs 1-3).
ACKNOWLEDGMENTS. Max Moulds is thanked for his guidance and assistance during field work and Sandy Leask provided technical assistance. Daniel Bickel critically reviewed an earlier draft. This research was partially supported by a postdoctoral fellowship from the Natural Sciences and Engineering Research Council of Canada to BJS.

\section{References}

Cumming, J.M., B.J. Sinclair \& D.M. Wood, 1995. Homology and phylogenetic implications of male genitalia in Diptera - Eremoneura. Entomologica Scandinavica 26: 121-151.

Hennig, W., 1958. Die Familien der Diptera Schizophora und ihre phylogenetischen Verwandtschaftsbeziehungen. Beitraege zur Entomologie 8: 505-688.

Lopes, H. de S., 1935. A sub-familia Rhinotorinae Williston (Dipt. - Rhopalomeridae). Archivos do Instituto de Biologia Vegetal 2: 19-26.

McAlpine, D.K., 1967. The Australian species of Diplogeomyza and allied genera (Diptera, Heleomyzidae). Proceedings of the Linnean Society of New South Wales 92: 74-106.

McAlpine, D.K., 1968. The genus Cairnsimyia Malloch (Diptera, Heleomyzidae, Rhinotorini). Records of the Australian Museum 27: 263-283.

McAlpine, D.K., 1985. The Australian genera of Heleomyzidae (Diptera: Schizophora) and a reclassification of the family into tribes. Records of the Australian Museum 36: 203251.

McAlpine, D.K., 1991. Review of the Australian kelp flies (Diptera: Coelopidae). Systematic Entomology 16: 29-84.

McAlpine, J.F., 1981. Morphology and terminology - adults. [Chapter] 2. Pp. 9-63. In J.F. McAlpine et al. eds. Manual of Nearctic Diptera, Vol. 1. Agriculture Canada Monograph 27: vi + 1-674.

McAlpine, J.F., 1987. Rhinotoridae [Chapter] 92. Pp. 989992. In J.F. McAlpine et al. eds. Manual of Nearctic Diptera, Vol. 2. Agriculture Canada Monograph 28: vi + 675-1332.

Malloch, J.R., 1934. Acalyptrata (concluded). Diptera of Patagonia and South Chile 6(5): 393-489, pl. 8.

Nix, H.A., 1991. Biogeography: pattern and process. Pp. 1139. In H.A. Nix \& M.A. Switzer eds. Rainforest Animals. Kowari 1: xii +112 .

Schneider, M.A., 1982. A comparative morphological study of the reproductive systems of some species of Tapeigaster Macquart (Diptera: Heleomyzidae). Proceedings of the Linnean Society of New South Wales 106: 59-65.

Accepted 11 October, 1995 